\title{
Luminescent Polyoxotungstoeuropate Anion-Pillared Layered Double Hydroxides
}

\author{
Filipa L. Sousa, ${ }^{[a]}$ Martyn Pillinger, ${ }^{[a]}$ Rute A. Sá Ferreira, ${ }^{[b]}$ Carlos M. Granadeiro, ${ }^{[a]}$ \\ Ana M. V. Cavaleiro, ${ }^{[a]}$ João Rocha, ${ }^{[a]}$ Luís D. Carlos, ${ }^{[b]}$ Tito Trindade, ${ }^{[a]}$ and \\ Helena I. S. Nogueira*[a]
}

Keywords: Layered double hydroxides / Layered compounds / Polyoxometalates / Host-guest systems / Luminescence

Novel luminescent polyoxometalate anion-pillared layered double hydroxides (LDHs) were prepared by aqueous ion exchange of a $\mathrm{Zn}-\mathrm{Al} \mathrm{LDH}$ precursor in nitrate form with the europium-containing polyoxotungstate anions $\left[\mathrm{EuW}_{10} \mathrm{O}_{36}\right]^{9-}$, $\left[\mathrm{Eu}\left(\mathrm{BW}_{11} \mathrm{O}_{39}\right)\left(\mathrm{H}_{2} \mathrm{O}\right)_{3}\right]^{6-}$ and $\left[\mathrm{Eu}\left(\mathrm{PW}_{11} \mathrm{O}_{39}\right)_{2}\right]^{11-}$. The hostguest interaction has a strong influence on the nature of the final intercalated species, as evidenced by elemental analy- sis, powder X-ray diffraction (XRD), infra-red (IR) and Raman spectroscopy, solid state magic-angle spinning (MAS) ${ }^{11} \mathrm{~B}$ and ${ }^{31} \mathrm{P}$ NMR spectroscopy, and photoluminescence spectroscopy.

() Wiley-VCH Verlag GmbH \& Co. KGaA, 69451 Weinheim, Germany, 2006)

\section{Introduction}

Layered double hydroxides are an important class of ionic lamellar solids with the general formula $\left[\mathrm{M}^{2+}{ }_{1-x} \mathrm{M}^{3+}{ }_{x}(\mathrm{OH})_{2}\right]\left(\mathrm{A}^{m-}\right)_{x / m} \cdot n \mathrm{H}_{2} \mathrm{O} \quad\left(\mathrm{M}^{2+}=\mathrm{Mg}^{2+}, \mathrm{Zn}^{2+}\right.$, $\mathrm{Ni}^{2+}$ etc., $\mathrm{M}^{3+}=\mathrm{Al}^{3+}, \mathrm{Cr}^{3+}, \mathrm{Ga}^{3+}$ etc). ${ }^{[1]}$ The positively charged layers, containing divalent and trivalent cations in octahedral positions, are separated by charge balancing anions and water molecules. The water molecules are connected to both the metal hydroxide layers and the interlayer anions through extensive hydrogen bonding. A range of organic or inorganic guests may be incorporated into LDHs by either ion exchange, direct synthesis or hydrothermal reconstruction of calcined precursors. ${ }^{[2,3]}$ In particular, intercalation chemistry has been explored with the aim of introducing catalytically active sites and photo- and electroactive species. Many different types of metal coordination compounds and oxometalates have been immobilized in LDHs, including phthalocyanines, cyanocomplexes, oxalate complexes and polyoxometalates (POMs) $\cdot{ }^{[4]}$

The first report of LDHs containing polyoxometalates concerned their use as exhaust gas and hydrocarbon conversion catalysts. ${ }^{[5]}$ Since then, a variety of iso- and heteropolyanions with different nuclearities and structures (Keggin, Dawson, Preyssler, Finke) have been incorporated into the interlayer space of these materials. ${ }^{[6-18]}$ Two factors assume considerable importance for the successful intercalation of polyoxometalates into an LDH compound. First, the heteropoly species should carry sufficient charge in order to be

[a] Department of Chemistry, CICECO, University of Aveiro, 3810-193 Aveiro, Portugal

E-mail: helena@dq.ua.pt

[b] Department of Physics, CICECO, University of Aveiro, 3810-193 Aveiro, Portugal spatially capable of compensating the host layer charge. Ideally, the charge should be higher than that necessary in order to increase the lateral separation of the anions in the interlayer and afford a material with microporosity. The second consideration is that the intercalated anion should be resistant to hydrolytic decomposition over the $\mathrm{pH}$ domain of stability of the LDH.

In recent years, heteropolyoxometalates incorporating lanthanide ions have excited interest because of their luminescence properties and potential use in lasers and luminescent materials. ${ }^{[19-23]}$ As a result, the preparation of hybrid materials containing these species is now being investigated. ${ }^{[24-32]}$ Francesconi and co-workers recently described $\mathrm{Mg}-\mathrm{Al} \mathrm{LDHs}$ intercalated by luminescent polyoxometalate anions with Dawson-like $\left[\mathrm{Eu}\left(\mathrm{H}_{2} \mathrm{O}\right)_{3}\left(\alpha_{2}-\mathrm{P}_{2} \mathrm{~W}_{17} \mathrm{O}_{61}\right)\right]^{7-}$ and Keggin-like $\left[\mathrm{Eu}_{2}\left(\mathrm{H}_{2} \mathrm{O}\right)_{2}\left(\mathrm{PW}_{11} \mathrm{O}_{39}\right)\right]^{4-}$ structures. ${ }^{[32]}$ In the present work, new polyoxotungstoeuropate anion-pillared layered double hydroxides were prepared by anion exchange reactions of a $\mathrm{Zn}-\mathrm{Al} \mathrm{LDH}$ precursor in nitrate form. Reaction of the wet precursor with the species $\left[\mathrm{EuW}_{10} \mathrm{O}_{36}\right]^{9-}$, $\left[\mathrm{Eu}\left(\mathrm{BW}_{11} \mathrm{O}_{39}\right)\left(\mathrm{H}_{2} \mathrm{O}\right)_{3}\right]^{6-}$ and $\left[\mathrm{Eu}\left(\mathrm{PW}_{11} \mathrm{O}_{39}\right)_{2}\right]^{1{ }^{1-}}$ gave the final materials, which were characterized by powder $\mathrm{X}$-ray diffraction, solid state NMR $\left({ }^{11} \mathrm{~B},{ }^{27} \mathrm{Al},{ }^{31} \mathrm{P}\right)$, infrared and Raman spectroscopy. The luminescence properties of the pillared LDHs were investigated in detail and are compared with those of the precursor polyoxotungstoeuropate anions.

\section{Results and Discussion}

\section{Synthesis of Polyoxotungstate Anion-Pillared Layered Double Hydroxides}

The layered double hydroxide starting material, denoted as $\mathrm{ZnAl}\left[\mathrm{NO}_{3}^{-}\right.$], was prepared using a standard coprecipi- 
Table 1. Representative reaction conditions and observed gallery heights for polyoxotungstoeuropate anion-pillared layered double hydroxides.

\begin{tabular}{lcccc}
\hline Sample & $n_{\mathrm{P}}{ }^{[\mathrm{a}]}[\mathrm{mmol}]$ & $C_{\mathrm{P}}{ }^{[\mathrm{b}]}\left[\mathrm{mol} \mathrm{dm}^{-3}\right]$ & $T\left[{ }^{\circ} \mathrm{C}\right]$ & $G^{[\mathrm{cc}]}[\AA]$ \\
\hline $\mathrm{ZnAl}\left[\mathrm{EuW}{ }_{10} \mathrm{O}_{36}{ }^{9-}\right]$ & 0.479 & 0.019 & 70 & 4.8 \\
$\mathrm{ZnAl}\left[\mathrm{Eu}\left(\mathrm{BW}_{11} \mathrm{O}_{39}\right)\left(\mathrm{H}_{2} \mathrm{O}\right)_{n}{ }^{6-}\right]$ & 0.175 & 0.017 & 60 & 9.6 \\
$\mathrm{ZnAl}\left[\mathrm{Eu}\left(\mathrm{PW}_{11} \mathrm{O}_{39}\right)_{2}{ }^{11-}\right]$ & 0.392 & 0.012 & 60 & 9.8 \\
\hline
\end{tabular}

[a] Number of moles of polyoxometalate treated with precursor slurry containing 0.25 g clay material. [b] Polyoxometalate concentration. [c] Gallery height, calculated by subtracting the layer thickness $(4.8 \AA)$ from the $d_{(003)}$ spacing.

tation method with special attention paid to the avoidance of carbonate interference. Anion-exchange reactions were then carried out on an aqueous slurry of $\mathrm{ZnAl}\left[\mathrm{NO}_{3}{ }^{-}\right]$with the polyoxotungstoeuropate anions $\left[\mathrm{EuW}_{10} \mathrm{O}_{36}\right]^{9-}$, [Eu$\left.\left(\mathrm{BW}_{11} \mathrm{O}_{39}\right)\left(\mathrm{H}_{2} \mathrm{O}\right)_{3}\right]^{6-}$ and $\left[\mathrm{Eu}\left(\mathrm{PW}_{11} \mathrm{O}_{39}\right)_{2}\right]^{11-}$ (Table 1). Analysis of the final polyoxotungstoeuropate anion-pillared layered double hydroxides was performed by ICP-AES and the metal atom ratios are presented in Table 2 . The $\mathrm{Zn} / \mathrm{Al}$ ratio was about $1.7(x=0.37)$ for all of the materials and therefore unchanged compared with that for the $\mathrm{ZnAl}\left[\mathrm{NO}_{3}{ }^{-}\right]$precursor. Polyoxometalate $\left(\mathrm{A}^{m-}\right)$ loadings were calculated for $\left[\mathrm{Zn}_{1-x} \mathrm{Al}_{x}(\mathrm{OH})_{2}\right]\left(\mathrm{A}^{m-}\right)_{x / m}$ as a percentage of the theoretical maximum calculated from the ICPdetermined mol fractions of aluminium.

Table 2. Metal atom ratios determined by ICP-AES for the polyoxotungstoeuropate anion-pillared layered double hydroxides.

\begin{tabular}{|c|c|c|c|c|c|}
\hline Sample & $\mathrm{Zn}$ & $\mathrm{Al}$ & $\mathrm{W}$ & $\mathrm{Eu}$ & $L^{[\mathrm{a}]}$ \\
\hline $\mathrm{ZnAl}\left[\mathrm{EuW}_{10} \mathrm{O}_{36}{ }^{9-}\right]$ & 1.73 & 1.00 & 1.02 & 0.09 & 92 \\
\hline $\begin{array}{l}\mathrm{ZnAl}[\mathrm{Eu}(\mathrm{B}- \\
\left.\left.\mathrm{W}_{11} \mathrm{O}_{39}\right)\left(\mathrm{H}_{2} \mathrm{O}\right)_{n}{ }^{6-}\right]\end{array}$ & 1.68 & 1.00 & 1.44 & 0.13 & 79 \\
\hline $\mathrm{ZnAl}\left[\mathrm{Eu}\left(\mathrm{PW}_{11} \mathrm{O}_{39}\right)_{2}{ }^{11-}\right]$ & 1.77 & 1.00 & 1.26 & 0.05 & 63 \\
\hline
\end{tabular}

[a] Polyoxometalate $\left(\mathrm{A}^{m-}\right)$ loadings as a percentage of the theoretical maximum calculated for $\left[\mathrm{Zn}_{1-x} \mathrm{Al}_{x}(\mathrm{OH})_{2}\right]\left(\mathrm{A}^{m-}\right)_{x / m}$ from the ICP-determined mol fractions of aluminium. The calculations assume that the only incorporated polyoxoanions are as indicated in the sample abbreviations.

\section{Powder X-ray Diffraction}

Figure 1 shows the powder XRD patterns obtained for the $\mathrm{ZnAl}\left[\mathrm{NO}_{3}{ }^{-}\right]$starting material and the pillared derivatives. Successful ion exchange of nitrate ions for POMs was revealed by the absence of reflections due to the starting material and the appearance of several new equally spaced $(00 l)$ harmonics with the (003) reflection having shifted to lower $2 \theta$ values. As is often observed for LDH-POM intercalates, ${ }^{[17]}$ the first-order peaks for the pillared phases have very low intensity. This may be related to the high $\mathrm{X}$ ray scattering power of the interlayer, out of phase with the brucite-like layer. ${ }^{[33]}$ The positions of the (003) reflections are confirmed by the presence of the peaks at about 7.25 (006), 4.85 (009), 3.60 (0012) and 2.90 (0015) $\AA$ for the phases with $d_{(003)} \approx 14.5 \AA$ [traces $(\mathrm{c})$ and $(\mathrm{d})$ ], and 4.86 (006) and 3.26 (009) $\AA$ for the phase with $d_{(003)} \approx 9.6 \AA$ [trace (b)]. The patterns also contain large and asymmetric $(h k l)$ reflections in the $33-50^{\circ}(2 \theta)$ range. This is characteristic of some disorder in the periodicity of the layers, such as a turbostratic effect or an intergrowth of the rhombohedral and hexagonal polytypes. ${ }^{[3]}$ Table 1 gives the gallery heights, calculated by subtracting the layer thickness $(4.8 \AA)$ from the $d_{(003)}$ spacing, for materials dried under reduced pressure in a vacuum desiccator. The anions [Eu$\left.\left(\mathrm{BW}_{11} \mathrm{O}_{39}\right)\left(\mathrm{H}_{2} \mathrm{O}\right)_{3}\right]^{6-}$ and $\left[\mathrm{Eu}\left(\mathrm{PW}_{11} \mathrm{O}_{39}\right)_{2}\right]^{11-}$ afforded pillared derivatives with a gallery height of about $10 \AA$. This layer separation is typical of LDHs pillared by Keggin-type or related structures and is consistent with a guest orientation in which the $C_{2}$ axis of the oxygen framework is perpendicular to the brucite-like layers. ${ }^{[8,11,12,18]}$ The positions and relative intensities of the $(00 l)$ reflections in traces (c) and (d) are entirely in agreement with results reported in the literature for related compounds, for example a $\mathrm{Zn}_{2} \mathrm{Al}$ LDH pillared by $\left[\alpha-\mathrm{H}_{2} \mathrm{~W}_{12} \mathrm{O}_{40}\right]^{6-}$ anions. ${ }^{\left[{ }^{[8}\right.} \mathrm{A}$ surprising result was obtained for the LDH-POM ZnAl[EuW $\left.{ }_{10} \mathrm{O}_{36}{ }^{9-}\right]$. The basal spacing of about $9.6 \AA$ is only slightly larger than that measured for the precursor $\mathrm{ZnAl}\left[\mathrm{NO}_{3}{ }^{-}\right]$(8.94 $\AA$ ). In the sodium tetrastrontium salt $\mathrm{NaSr}_{4}\left[\mathrm{EuW}_{10} \mathrm{O}_{36}\right] \cdot 34.5 \mathrm{H}_{2} \mathrm{O}$ the structure of the decatungstoeuropate anion consists of two $\mathrm{W}_{5} \mathrm{O}_{18}{ }^{6-}$ units (derived from the hexatungstate $\mathrm{W}_{6} \mathrm{O}_{19}{ }^{2-}$

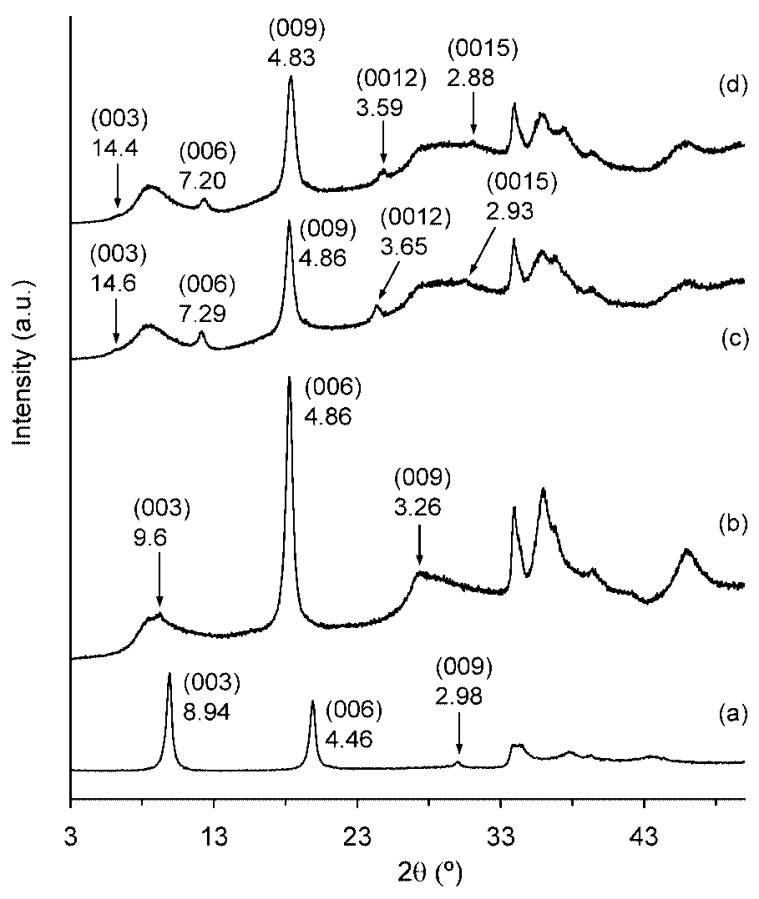

Figure 1. Powder XRD patterns for the $\mathrm{LDH}$ intercalates $\mathrm{ZnAl}\left[\mathrm{NO}_{3}{ }^{-}\right]$(a), $\mathrm{ZnAl}\left[\mathrm{EuW}_{10} \mathrm{O}_{36}{ }^{9-}\right]$ (b), $\mathrm{ZnAl}\left[\mathrm{Eu}\left(\mathrm{PW}_{11} \mathrm{O}_{39}\right)_{2}{ }^{11-}\right]$ (c) and $\mathrm{ZnAl}\left[\mathrm{Eu}\left(\mathrm{BW}_{11} \mathrm{O}_{39}\right)\left(\mathrm{H}_{2} \mathrm{O}\right)_{n}{ }^{6}\right]$ (d). Values adjacent to the diffraction peaks are $d$ spacings in $\AA$ for several $00 l$ harmonics. 
by removal of one $\mathrm{W}=\mathrm{O}$ group) linked by the europium ion. ${ }^{[35]}$ The four former bridging oxygen atoms from each $\mathrm{W}_{5} \mathrm{O}_{18}{ }^{6-}$ unit form a square antiprism around $\mathrm{Eu}$. The shortest dimension of the $\left[\mathrm{EuW}_{10} \mathrm{O}_{36}\right]^{9-}$ anion is about $10 \AA$ (including van der Waals radii for the oxygen atoms). A basal spacing of at least $14.8 \AA$ would therefore be expected for an LDH intercalate containing this anion. The observed basal spacing is much shorter and is in fact only compatible with the presence of two oxygen-atom layers in the interslab space. For example, a very similar powder XRD pattern was reported by Vaysse et al. for a NiCo LDH intercalated by $\mathrm{W}_{2} \mathrm{O}_{7}{ }^{2-}$ anions. ${ }^{[36]}$ All of the diffraction patterns for the exchanged products contain a broad and asymmetric peak at $2 \theta=5-11^{\circ}$. This is a common feature for LDH-POM composites and is often attributed to a quasi-crystalline $\mathrm{M}^{2+} / \mathrm{M}^{3+}$ salt of the POM formed in low quantities, ${ }^{[11]}$ although alternative origins have also been claimed. ${ }^{[37]}$

\section{Infrared and Raman Spectroscopy}

The infrared and Raman spectra of the polyoxotungstoeuropate anion-pillared layered double hydroxides showed that the exchange of nitrate anions for polyoxotungstate anions was almost complete (by the absence in the infrared spectra of the nitrate $v_{3}$ absorption band at $1384 \mathrm{~cm}^{-1}$, or in one case just a very weak IR band present) and also that there was no carbonate present in these materials (by the absence in the infrared spectra of the carbonate $v_{3}$ absorption band at $1370 \mathrm{~cm}^{-1}$ ). The intercalation of polyoxoanions into the layered double hydroxide was clearly shown by the presence in the infrared and Raman spectra of several bands in the range $700-1200 \mathrm{~cm}^{-1}$, on top of the lattice vibrations of the host (Figure 2, Table 3), assigned to $\mathrm{X}-\mathrm{O}$ stretch $(\mathrm{X}=\mathrm{B}$ or $\mathrm{P})$, the terminal $\mathrm{W}=\mathrm{O}$ stretch $(918$ $989 \mathrm{~cm}^{-1}$ ), and the $\mathrm{W}-\mathrm{O}-\mathrm{W}$ corner or edge-shared stretching modes $\left(700-900 \mathrm{~cm}^{-1}\right) \cdot{ }^{[38,39]}$ For $\mathrm{ZnAl}\left[\mathrm{Eu}\left(\mathrm{PW}_{11} \mathrm{O}_{39}\right)_{2}{ }^{11-}\right]$ and $\mathrm{ZnAl}\left[\mathrm{Eu}\left(\mathrm{BW}_{11} \mathrm{O}_{39}\right)\left(\mathrm{H}_{2} \mathrm{O}\right)_{n}{ }^{6}\right]$ the similarity of the guest vibrations to those for the corresponding polyoxotungstoeuropate salts indicates that the structures of the core lacunary anions, i.e. $\mathrm{PW}_{11} \mathrm{O}_{39}{ }^{7-}$ and $\mathrm{BW}_{11} \mathrm{O}_{39}{ }^{9-}$, were unaffected by the ion-exchange reaction. In contrast, the bands

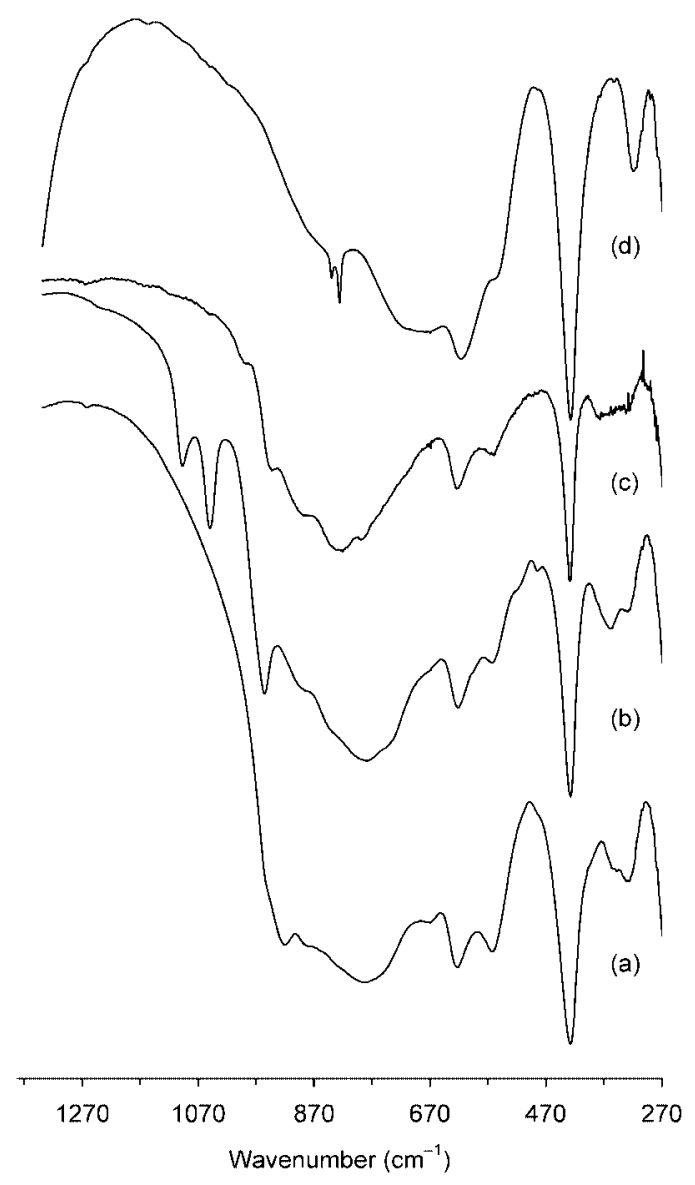

Figure 2. Infrared spectra (transmission mode) for the LDH intercalates $\mathrm{ZnAl}\left[\mathrm{EuW}_{10} \mathrm{O}_{36}{ }^{9-}\right]$ (a), $\mathrm{ZnAl}\left[\mathrm{Eu}\left(\mathrm{PW}_{11} \mathrm{O}_{39}\right)_{2}{ }^{11-}\right]$ (b), $\mathrm{ZnAl}\left[\mathrm{Eu}\left(\mathrm{BW}_{11} \mathrm{O}_{39}\right)\left(\mathrm{H}_{2} \mathrm{O}\right)_{n}^{6-}\right]$ (c) and $\mathrm{ZnAl}\left[\mathrm{NO}_{3}^{-}\right]$(d).

Table 3. Vibrational data for the polyoxotungstoeuropate anions and the respective anion-pillared layered double hydroxides. ${ }^{\text {[a] }}$

\begin{tabular}{|c|c|c|c|c|c|}
\hline \multirow[t]{2}{*}{ Sample } & \multirow{2}{*}{$\begin{array}{l}\text { Clay lattice and nitrate vibrations } \\
{\left[\mathrm{cm}^{-1}\right]}\end{array}$} & \multicolumn{3}{|c|}{ Polyoxoanion stretching frequency assignment $\left[\mathrm{cm}^{-1}\right]$} & \multirow[b]{2}{*}{$\mathrm{W}-\mathrm{O}-\mathrm{W}_{\text {edge-shared }}$} \\
\hline & & $\mathrm{X}-\mathrm{O}(\mathrm{X}=\mathrm{B}$ or $\mathrm{P})$ & $\mathrm{W}=\mathrm{O}_{\text {terminal }}$ & $\mathrm{W}-\mathrm{O}-\mathrm{W}_{\text {corner-shared }}$ & \\
\hline $\mathrm{ZnAl}\left[\mathrm{NO}_{3}{ }^{-}\right]$ & $1623 \mathrm{~m}, 1383 \mathrm{vs}, 621 \mathrm{~s}, 560 \mathrm{~s}, 427 \mathrm{~s}$ & & & & \\
\hline \multirow[t]{2}{*}{$\mathrm{Na}_{9}\left[\mathrm{EuW}_{10} \mathrm{O}_{36}\right]$} & & & 932 vs & & $841 \mathrm{vs}, 707 \mathrm{~s}$ \\
\hline & & & 968 vs, 946 vs & & $891 s, 842 w$ \\
\hline \multirow[t]{2}{*}{$\mathrm{ZnAl}\left[\mathrm{EuW}_{10} \mathrm{O}_{36}{ }^{9-}\right]$} & $1624 \mathrm{~m}, 624 \mathrm{~s}, 561 \mathrm{~s}, 427 \mathrm{vs}$ & & $918 \mathrm{~s}$ & & $883 \mathrm{~m}, 784 \mathrm{~s}$ \\
\hline & & & $963 \mathrm{sh}, 941$ vs & & $863 m$ \\
\hline \multirow[t]{2}{*}{$\mathrm{K}_{5} \mathrm{H}\left[\mathrm{Eu}\left(\mathrm{BW}_{11} \mathrm{O}_{39}\right)\left(\mathrm{H}_{2} \mathrm{O}\right)_{3}\right]$} & & & $943 \mathrm{~s}$ & $883 \mathrm{~s}$ & $\begin{array}{l}830 \mathrm{vs}, 790 \mathrm{~s}, \\
758 \mathrm{~m}\end{array}$ \\
\hline & & $909 \mathrm{~m}$ & 972 vs & $874 m$ & $820 w$ \\
\hline \multirow[t]{2}{*}{$\mathrm{ZnAl}\left[\mathrm{Eu}\left(\mathrm{BW}_{11} \mathrm{O}_{39}\right)\left(\mathrm{H}_{2} \mathrm{O}\right)_{n}{ }^{6-}\right]$} & $1623 \mathrm{~m}, 1384 \mathrm{w}, 623 \mathrm{~s}, 560 \mathrm{~m}, 429 \mathrm{vs}$ & & $943 \mathrm{~m}$ & $887 \mathrm{~s}$ & 820 vs, 789 s \\
\hline & & $900 \mathrm{sh}$ & 969 vs & $867 \mathrm{~m}$ & \\
\hline \multirow[t]{2}{*}{$\mathrm{K}_{11}\left[\mathrm{Eu}\left(\mathrm{PW}_{11} \mathrm{O}_{39}\right)_{2}\right]$} & & $1102 \mathrm{~s}, 1048 \mathrm{~s}$ & 952 vs & $892 \mathrm{~s}$ & $\begin{array}{l}824 \mathrm{~s}, 773 \mathrm{vs}, \\
732 \mathrm{~s}\end{array}$ \\
\hline & & & 987 vs, $973 \mathrm{~s}$ & $895 m, 867 m$ & \\
\hline \multirow[t]{2}{*}{$\mathrm{ZnAl}\left[\mathrm{Eu}\left(\mathrm{PW}_{11} \mathrm{O}_{39}\right)_{2}{ }^{11-}\right]$} & $1624 \mathrm{~m}, 621 \mathrm{~s}, 564 \mathrm{~m}, 427 \mathrm{vs}$ & $1098 \mathrm{~m}, 1049 \mathrm{~s}$ & $955 \mathrm{~s}$ & $882 \mathrm{~m}$ & $\begin{array}{l}830 \mathrm{sh}, 779 \mathrm{vs}, \\
730 \mathrm{sh}\end{array}$ \\
\hline & & & 989 vs, 973 vs & $898 s h, 867 s h$ & \\
\hline
\end{tabular}

[a] Infrared and Raman (in italics) data: vs, very strong; s, strong; m, medium; w, weak; sh, shoulder. 
attributed to the guest species in $\mathrm{ZnAl}\left[\mathrm{EuW}_{10} \mathrm{O}_{36}{ }^{9}{ }^{-}\right]$are significantly different from those exhibited by solid $\mathrm{Na}_{9}\left[\mathrm{EuW}_{10} \mathrm{O}_{36}\right]$, for example the $\mathrm{W}=\mathrm{O}$ stretch for the guest species is shifted by $14 \mathrm{~cm}^{-1}$ and the $\mathrm{W}-\mathrm{O}-\mathrm{W}$ stretching modes present a set of maxima at wavenumbers that are different from those for $\mathrm{Na}_{9}\left[\mathrm{EuW}_{10} \mathrm{O}_{36}\right]$. These changes indicate that the intercalated species have a different structure, in agreement with the powder XRD data and the photoluminescence results discussed below.

\section{${ }^{11} \mathrm{~B},{ }^{27} \mathrm{Al}$ and ${ }^{31} \mathrm{P}$ MAS NMR}

Figure 3 shows the ${ }^{11} \mathrm{~B}$ MAS NMR spectrum of the pillared $\mathrm{LDH} \mathrm{ZnAl}\left[\mathrm{Eu}\left(\mathrm{BW}_{11} \mathrm{O}_{39}\right)\left(\mathrm{H}_{2} \mathrm{O}\right)_{n}{ }^{6-}\right]$. The spectrum consists of one main peak (with a broad low frequency shoulder) centred at $\delta=-6.8 \mathrm{ppm}$, with a full-width at halfmaximum (fwhm) of about $580 \mathrm{~Hz}$. For comparison, the potassium salt $\mathrm{K}_{5}\left[\alpha-\mathrm{BW}_{12} \mathrm{O}_{40}\right]$ displays a single sharp (fwhm $15 \mathrm{~Hz}$ ) and symmetric resonance at $\delta=-7.4 \mathrm{ppm}$, while the spectrum of lacunary $\mathrm{K}_{6.5} \mathrm{Na}_{1.5}\left[\mathrm{HBW}_{11} \mathrm{O}_{39}\right]$ (fwhm $130 \mathrm{~Hz}$ ) consists of a second-order quadrupole powder pattern, showing that boron is in a distorted tetrahedral coordination. ${ }^{[31,40]}$ The corresponding lanthanopolyoxotungstoborate salt, $\mathrm{K}_{5} \mathrm{H}\left[\mathrm{Eu}\left(\mathrm{BW}_{11} \mathrm{O}_{39}\right)\left(\mathrm{H}_{2} \mathrm{O}\right)_{3}\right]$, gives rise to a much broader peak (fwhm $440 \mathrm{~Hz}$ ) at $0.1 \mathrm{ppm}$ (Figure 3) ${ }^{[31]}$ As described in ref. ${ }^{[31]}$, the broadening of the resonance as compared with the monovacant Keggin polyoxotungstoborate is due to insertion of the europium ion into the polyoxoanion. Hence, the observation of the broad resonance at $\delta=-6.8 \mathrm{ppm}$ in the ${ }^{11} \mathrm{~B}$ MAS NMR spectrum of the pillared $\mathrm{LDH} \mathrm{ZnAl}\left[\mathrm{Eu}\left(\mathrm{BW}_{11} \mathrm{O}_{39}\right)\left(\mathrm{H}_{2} \mathrm{O}\right)_{n}{ }^{6}\right]$ suggests that the coordination of the europium ions to the polyoxotungstoborate was maintained after intercalation into the LDH host. Taking into account the results from powder XRD, elemental analysis (which gave the W/Eu molar ratio as 11.1), vibrational spectroscopy and photoluminescence studies (see below), we propose that the resonance at $\delta=$ $-6.8 \mathrm{ppm}$ is due to intercalated monomeric 1:1 [Eu$\left.\left(\mathrm{BW}_{11} \mathrm{O}_{39}\right)\left(\mathrm{H}_{2} \mathrm{O}\right)_{n}\right]^{6-}$ anions. The crystal structure of the potassium salt, $\mathrm{K}_{5} \mathrm{H}\left[\mathrm{Eu}\left(\mathrm{BW}_{11} \mathrm{O}_{39}\right)\left(\mathrm{H}_{2} \mathrm{O}\right)_{3}\right]$, is unknown, but by comparison with the analogous $\mathrm{Ce}^{3+}$ compound it is likely that a polymeric structure exists in the solid-state, comprising Keggin-type anions bridged by $\mathrm{Eu}^{3+}$ cations. ${ }^{[1]}$ The difference in the chemical shifts for the pillared LDH $(\delta=-6.8 \mathrm{ppm})$ and the potassium salt $(\delta=0.1 \mathrm{ppm})$ may therefore be attributed to the dissociation of the polymer into the monomeric building blocks, and the intercalation of these species into the host LDH. In support of this, it has previously been shown that polymeric lanthanopolyoxotungstosilicates dissociate in aqueous solution. ${ }^{[42]}$ As mentioned above, the peak at $\delta=-6.8 \mathrm{ppm}$ in the ${ }^{11} \mathrm{~B}$ MAS NMR spectrum of the pillared LDH has a weaker low frequency shoulder. This may be due to a small amount of an insoluble $\mathrm{K}^{+} / \mathrm{Zn}^{2+} / \mathrm{Al}^{3+}$ salt of the POM $\left[\mathrm{Eu}\left(\mathrm{BW}_{11} \mathrm{O}_{39}\right)\left(\mathrm{H}_{2} \mathrm{O}\right)_{3}\right]^{6-}$ (related with the broad peak at $2 \theta=5-11^{\circ}$ in the powder XRD pattern).

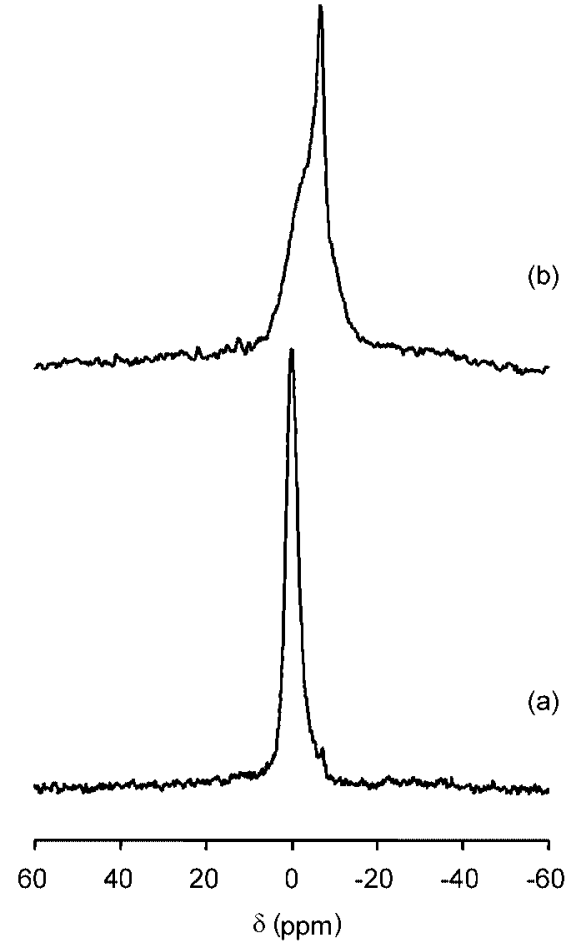

Figure 3. ${ }^{11} \mathrm{~B}$ MAS NMR spectra of (a) $\mathrm{K}_{5} \mathrm{H}\left[\mathrm{Eu}\left(\mathrm{BW}_{11} \mathrm{O}_{39}\right)\right.$ $\left.\left(\mathrm{H}_{2} \mathrm{O}\right)_{3}\right]$ and (b) $\mathrm{ZnAl}\left[\mathrm{Eu}\left(\mathrm{BW}_{11} \mathrm{O}_{39}\right)\left(\mathrm{H}_{2} \mathrm{O}\right)_{n}{ }^{6-}\right]$.

The ${ }^{31} \mathrm{P}$ MAS NMR spectrum of solid $\mathrm{K}_{11}\left[\mathrm{Eu}\left(\mathrm{PW}_{11} \mathrm{O}_{39}\right)_{2}\right]$ presents a peak centred at $0.3 \mathrm{ppm}$ with a high frequency shoulder at $\delta=-1.5 \mathrm{ppm}$ (not shown). The presence of two peaks is probably due to slight asymmetry in the structure with respect to the two $\left\{\mathrm{PW}_{11} \mathrm{O}_{39}\right\}$ moieties. ${ }^{[43]}$ An aqueous solution of this potassium salt exhibits one resonance at $\delta$ $=-0.3 \mathrm{ppm}$, suggesting that the $1: 2$ structure is stable in solution and that the two phosphorus atoms are equivalent. ${ }^{[43]} \mathrm{A}$ complicated ${ }^{31} \mathrm{P}$ MAS NMR spectrum was obtained for the pillared $\mathrm{LDH} \mathrm{ZnAl}\left[\mathrm{Eu}\left(\mathrm{PW}_{11} \mathrm{O}_{39}\right)_{2}{ }^{11-}\right]$, comprising several overlapping peaks between ca. 5 and $-12 \mathrm{ppm}$ (Figure 4). Spectral deconvolution gave four main components at $-12.2,-10.1,-2.5$ and $2.1 \mathrm{ppm}$ in 1.0:1.0:5.3:1.9 intensity ratios. A much weaker peak was also found at $\delta=-7.7 \mathrm{ppm}$ with a relative integration of 0.2 . The major signal at $\delta=-2.5 \mathrm{ppm}$ is assigned to intercalated $\left[\mathrm{Eu}\left(\mathrm{PW}_{11} \mathrm{O}_{39}\right)_{2}\right]^{11-}$ anions. The two overlapping peaks at -12.2 and $-10.1 \mathrm{ppm}$ are attributed to uncoordinated $\left[\mathrm{PW}_{11} \mathrm{O}_{39}\right]^{7-}$ anions in slightly different environments, and the peak at ca. $2.1 \mathrm{ppm}$ is assigned to co-intercalated 1:1 $\left[\mathrm{Eu}\left(\mathrm{PW}_{11} \mathrm{O}_{39}\right)\left(\mathrm{H}_{2} \mathrm{O}\right)_{n}\right]^{4-}$ anions. ${ }^{[43]}$ If we exclude the weak resonance at $\delta=-7.7 \mathrm{ppm}$ (which, at present, we are unable to assign) and assume that there are no other tungsten or europium-containing species present, the peak area integrated intensities allow a value of 22.3 to be estimated for the overall $\mathrm{W} / \mathrm{Eu}$ molar ratio. This is in reasonable agreement with the value of 25 found by elemental analysis.

All compounds were also characterized by ${ }^{27} \mathrm{Al}$ MAS NMR spectroscopy. The spectra for the precursor $\mathrm{ZnAl}\left[\mathrm{NO}_{3}{ }^{-}\right]$and $\mathrm{ZnAl}[\mathrm{POM}]$ samples present a sharp reso- 


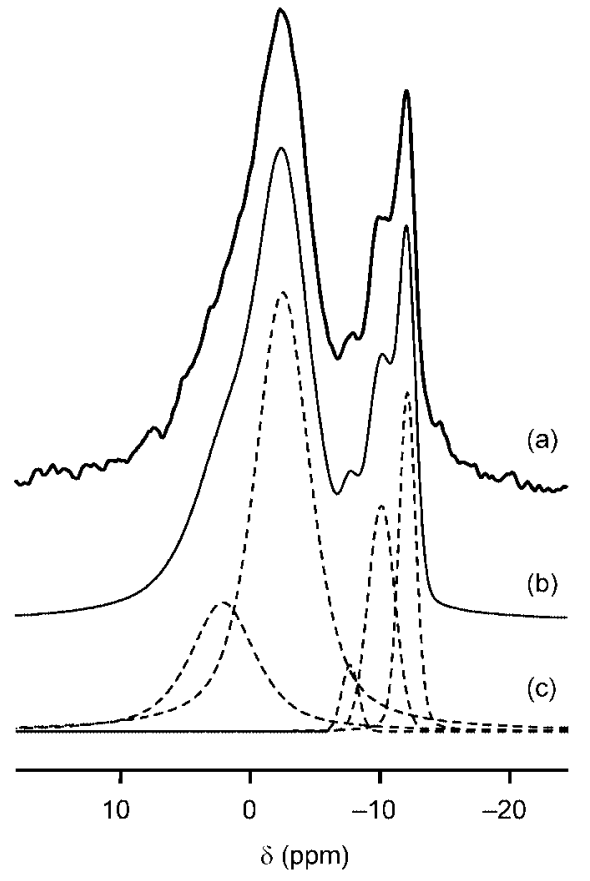

Figure 4. Experimental (a) and simulated (b) ${ }^{31} \mathrm{P}$ MAS NMR spectra of $\mathrm{ZnAl}\left[\mathrm{Eu}\left(\mathrm{PW}_{11} \mathrm{O}_{39}\right)_{2}{ }^{11-}\right]$. The individual peaks for the deconvolution are also shown (c).

nance centred at $14.5-15.6 \mathrm{ppm}$ that indicates the presence of octahedral aluminium only. ${ }^{[44]}$

\section{Photoluminescence}

Figure 5 shows the room-temperature photoluminescence excitation (PLE) spectra of the europium-containing polyoxotungstate materials monitored within the ${ }^{5} \mathrm{D}_{0} \rightarrow{ }^{7} \mathrm{~F}_{2}$ lines. The spectra are mainly composed of a series of straight lines ascribed to intra- $4 \mathrm{f}^{6}$ transitions. Only the spectrum of $\mathrm{Na}_{9}\left[\mathrm{EuW}_{10} \mathrm{O}_{36}\right]$ presents a large broad band in the UV spectral region with two main peaks around 270 and $320 \mathrm{~nm}$. The origin of the PLE components may be related to ligand-to-europium charge-transfer (LMCT) transitions resulting from the interaction between the europium ion and the POM, in particular LMCT states associated with $\mathrm{O} \rightarrow \mathrm{Eu}$ and $\mathrm{O} \rightarrow \mathrm{W}$ transitions as already reported for other polyoxometalates containing $\mathrm{Eu}^{3+}$ ions. ${ }^{[31,45,46]}$ The higher intensity of the $\mathrm{Eu}^{3+}$ straight lines indicate that the $\mathrm{Eu}^{3+}$ ions are excited via direct excitation into the intra- $4 f^{6}$ levels, and only for $\mathrm{Na}_{9}\left[\mathrm{EuW}_{10} \mathrm{O}_{36}\right]$ is the sensitized process comparable with direct excitation into the $\mathrm{Eu}^{3+}$ levels.

The incorporation of the europium-containing polyoxotungstate into the $\mathrm{Zn}-\mathrm{Al} \mathrm{LDH}$ (to give the material designated as $\mathrm{ZnAl}\left[\mathrm{EuW}_{10} \mathrm{O}_{36}{ }^{9}\right]$ ) induces the appearance of a low-intensity band centred around $292 \mathrm{~nm}$. For the other two LDH compounds the intensity of this band is negligible. The higher intensity of the $\mathrm{Eu}^{3+}$ lines for all of the ion-exchanged LDH materials indicates that the excitation occurs essentially via direct lanthanide excitation, rather

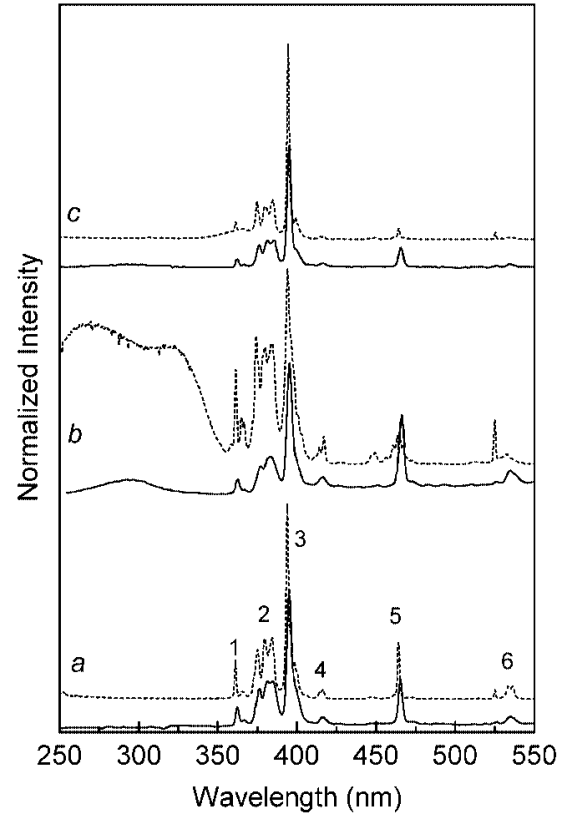

Figure 5. Room-temperature excitation spectra monitored around $612 \mathrm{~nm}$ of the polyoxotungstoeuropates (dotted lines) and the corresponding layered double hydroxide intercalates (solid lines): (a) $\mathrm{K}_{5} \mathrm{H}\left[\mathrm{Eu}\left(\mathrm{BW}_{11} \mathrm{O}_{39}\right)\left(\mathrm{H}_{2} \mathrm{O}\right)_{3}\right], \quad \mathrm{ZnAl}\left[\mathrm{Eu}\left(\mathrm{BW}_{11} \mathrm{O}_{39}\right)\left(\mathrm{H}_{2} \mathrm{O}\right)_{n}{ }^{6-}\right], \quad$ (b) $\mathrm{Na}_{9}\left[\mathrm{EuW}_{10} \mathrm{O}_{36}\right], \mathrm{ZnAl}\left[\mathrm{EuW}_{10} \mathrm{O}_{36}{ }^{9-}\right]$, (c) $\mathrm{K}_{11}\left[\mathrm{Eu}\left(\mathrm{PW}_{11} \mathrm{O}_{39}\right)_{2}\right] \cdot n \mathrm{H}_{2} \mathrm{O}$, $\mathrm{ZnAl}\left[\mathrm{Eu}\left(\mathrm{PW}_{11} \mathrm{O}_{39}\right)_{2}{ }^{11-}\right]$.

than by an efficient sensitized process involving the lanthanide ion ligands.

The changes induced in the $\mathrm{Eu}^{3+}$ local structures due to intercalation of the polyoxotungstate anions in the LDH host were further investigated by comparison of the respective emission (PL) spectra. The spectra shown in Figure 6 were obtained for different excitation wavelengths, selected according to the excitation spectra in Figure 5, namely direct excitation into the $\mathrm{Eu}^{3+}$ intra-4f ${ }^{6}$ levels $\left({ }^{5} \mathrm{~L}_{6}, 395 \mathrm{~nm}\right)$, and within the UV band, at $320 \mathrm{~nm}$ for $\mathrm{K}_{11}\left[\mathrm{Eu}\left(\mathrm{PW}_{11} \mathrm{O}_{39}\right)_{2}\right]$. $n \mathrm{H}_{2} \mathrm{O}$ and $292 \mathrm{~nm}$ for the LDH materials. We will first consider the emission features of the polyoxotungstate salts. All of the spectra display the well-known $\mathrm{Eu}^{3+}$ orange-red emission ascribed to transitions between the first excited state ${ }^{5} \mathrm{D}_{0}$ and the ${ }^{7} \mathrm{~F}_{0-4}$ levels of the ground multiplet. No emission from the ligands could be detected. The profile of the PL lines, namely the energy, fwhm and number of components, depends on the sample, confirming that the $\mathrm{Eu}^{3+}$ local environments in the three compounds are different. For $\mathrm{K}_{5} \mathrm{H}\left[\mathrm{Eu}\left(\mathrm{BW}_{11} \mathrm{O}_{39}\right)\left(\mathrm{H}_{2} \mathrm{O}\right)_{3}\right]$ and $\mathrm{K}_{11}[\mathrm{Eu}-$ $\left.\left(\mathrm{PW}_{11} \mathrm{O}_{39}\right)_{2}\right] \cdot n \mathrm{H}_{2} \mathrm{O}$, the higher number of Stark components, in particular for the ${ }^{5} D_{0} \rightarrow{ }^{7} F_{1,2}$ transitions ( 3 and 4 lines, respectively), suggests that the metal ion local structure is characterized by a low symmetry group without an inversion centre according to the higher intensity of the ${ }^{5} \mathrm{D}_{0} \rightarrow{ }^{7} \mathrm{~F}_{2}$ transition. The spectrum of $\mathrm{Na}_{9}\left[\mathrm{EuW}_{10} \mathrm{O}_{36}\right]$ has already been reported. ${ }^{[45]}$ The compound prepared by us revealed a different spectrum with singular features, in particular the absence of the ${ }^{5} \mathrm{D}_{0} \rightarrow{ }^{7} \mathrm{~F}_{0}$ transition and an abnormally high intensity for the ${ }^{5} \mathrm{D}_{0} \rightarrow{ }^{7} \mathrm{~F}_{4}$ transition. A deeper investigation of these singular emission features lies 
beyond the scope of the present manuscript and will be discussed in a forthcoming study. For all of the polyoxotungstates, upon changing the excitation wavelength, no major variations are observed in the energy, fwhm and number of emission lines, suggesting that all of the metal ions occupy the same average local coordination site within each polyoxotungstate. This conclusion is further supported by the analyses of the decay curves monitored within the ${ }^{5} \mathrm{D}_{0} \rightarrow{ }^{7} \mathrm{~F}_{2}$ transition for an excitation wavelength around $395 \mathrm{~nm}$. The decay curves are well reproduced by a single exponential function from which the ${ }^{5} \mathrm{D}_{0}$ lifetime was extracted (Table 4). For the $\left[\mathrm{EuW}_{10} \mathrm{O}_{36}\right]^{9-}$ anion the decay curve was also monitored for an excitation wavelength within the large broad band in the PLE spectrum, revealing a ${ }^{5} \mathrm{D}_{0}$ lifetime value similar to that obtained for direct excitation in the ${ }^{5} \mathrm{~L}_{6} \mathrm{Eu}^{3+}$ level.

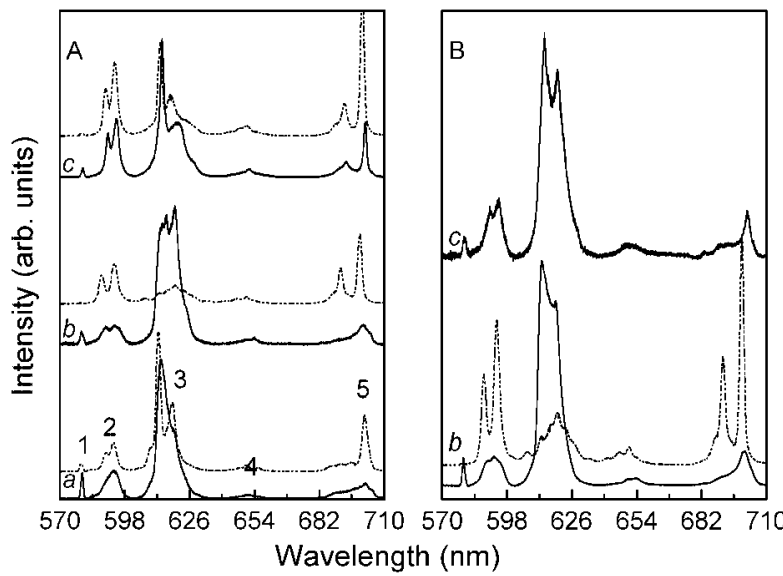

Figure 6. Room-temperature emission spectra of the polyoxotungstoeuropates (dotted lines) and the corresponding layered double hydroxide intercalates (solid lines): (a) $\mathrm{K}_{5} \mathrm{H}\left[\mathrm{Eu}\left(\mathrm{BW}_{11} \mathrm{O}_{39}\right)\right.$ $\left.\left(\mathrm{H}_{2} \mathrm{O}\right)_{3}\right], \mathrm{ZnAl}\left[\mathrm{Eu}\left(\mathrm{BW}_{11} \mathrm{O}_{39}\right)\left(\mathrm{H}_{2} \mathrm{O}\right)_{n}{ }^{6-}\right]$, (b) $\mathrm{Na}_{9}\left[\mathrm{EuW}_{10} \mathrm{O}_{36}\right]$, $\mathrm{ZnAl}-$ $\left[\mathrm{EuW}_{10} \mathrm{O}_{36}{ }^{9-}\right], \quad$ (c) $\mathrm{K}_{11}\left[\mathrm{Eu}\left(\mathrm{PW}_{11} \mathrm{O}_{39}\right)_{2}\right] \cdot n \mathrm{H}_{2} \mathrm{O}, \quad \mathrm{ZnAl}\left[\mathrm{Eu}\left(\mathrm{PW}_{11^{-}}\right.\right.$ $\left.\mathrm{O}_{39}\right)_{2}{ }^{11-}$, excited around A: $395 \mathrm{~nm}$ and B: $292-320 \mathrm{~nm}$.

Table $4 .{ }^{5} \mathrm{D}_{0}$ lifetimes, $\tau$, monitored around $611 \mathrm{~nm}$ at different excitation wavelengths (292 and $395 \mathrm{~nm}$ ) for the polyoxotungstoeuropate anions and the respective anion-pillared layered double hydroxides.

\begin{tabular}{lll}
\hline Sample & $\begin{array}{l}\tau[\mathrm{ms}] \\
292 \mathrm{~nm}\end{array}$ & $395 \mathrm{~nm}$ \\
\hline $\mathrm{ZnAl}\left[\mathrm{Eu}\left(\mathrm{BW}_{11} \mathrm{O}_{39}\right)\left(\mathrm{H}_{2} \mathrm{O}\right)_{n}{ }^{6-}\right]$ & $0.260 \pm 0.002$ & $0.255 \pm 0.002$ \\
{$\left[\mathrm{Eu}\left(\mathrm{BW}_{11} \mathrm{O}_{39}\right)\left(\mathrm{H}_{2} \mathrm{O}\right)_{3}\right]^{6-}$} & - & $0.302 \pm 0.001$ \\
$\mathrm{ZnAl}\left[\mathrm{EuW}_{10} \mathrm{O}_{36}{ }^{9-}\right]$ & $0.347 \pm 0.003$ & $0.289 \pm 0.001$ \\
{$[\mathrm{EuW}$} & $2.976 \pm 0.002$ & $2.929 \pm 0.005$ \\
& $0.324 \pm 0.002$ & $0.326 \pm 0.003$ \\
$\left.\mathrm{ZnAl}\left[\mathrm{Eu}\left(\mathrm{PW}_{11}\right]^{9-} \mathrm{O}_{39}\right)_{2}{ }^{11-}\right]$ & and & and \\
{$[\mathrm{Eu}(\mathrm{PW}$} & $2.950 \pm 0.118$ & $3.050 \pm 0.038$ \\
& - & $2.084 \pm 0.002$ \\
\hline
\end{tabular}

The emission spectra of the LDH-POM intercalates obtained by direct excitation into the lanthanide ion levels resemble those of the precursor polyoxotungstoeuropate salts with the exception of $\mathrm{ZnAl}\left[\mathrm{EuW}_{10} \mathrm{O}_{36}{ }^{9-}\right.$, which presents an inversion of the relative intensities of the ${ }^{5} \mathrm{D}_{0} \rightarrow{ }^{7} \mathrm{~F}_{1,2}$ transitions, indicating that the $\mathrm{Eu}^{3+}$ local coordination site in the ion-exchanged material is different from that in $\mathrm{Na}_{9}\left[\mathrm{EuW}_{10} \mathrm{O}_{36}\right]$, in particular the local symmetry group around the metal ion lost the inversion centre after incorporation in the LDH. This is consistent with the results from powder XRD and vibrational spectroscopy. For the remaining polyoxotungstates, minor changes were measured in the $\mathrm{PL}$ spectra. For $\mathrm{ZnAl}\left[\mathrm{Eu}\left(\mathrm{PW}_{11} \mathrm{O}_{39}\right)_{2}{ }^{11-}\right]$, an increase was observed in the relative intensity of the ${ }^{5} \mathrm{D}_{0} \rightarrow{ }^{7} \mathrm{~F}_{4}$ transition, while for $\mathrm{ZnAl}\left[\mathrm{Eu}\left(\mathrm{BW}_{11} \mathrm{O}_{39}\right)\left(\mathrm{H}_{2} \mathrm{O}\right)_{n}{ }^{6}\right]$ an enlargement of the emission lines was detected. These minor changes in the PL spectra are compatible with changes in the $\mathrm{Eu}^{3+}$ second coordination shell, induced by the LDH incorporation. However, upon decreasing the excitation wavelength to $292 \mathrm{~nm}$, major changes in the PL profile were recorded, in particular for $\mathrm{ZnAl}\left[\mathrm{EuW}_{10} \mathrm{O}_{36}{ }^{9}{ }^{-}\right]$and $\mathrm{ZnAl}[\mathrm{Eu}-$ $\left(\mathrm{PW}_{11} \mathrm{O}_{39}\right)_{2}{ }^{11-}$, which must be related with the presence of another $\mathrm{Eu}^{3+}$ local site that was not observed in the precursor. This metal ion local coordination site must be related with the appearance of the large broad band in the PLE spectra. The spectrum of $\mathrm{ZnAl}\left[\mathrm{Eu}\left(\mathrm{BW}_{11} \mathrm{O}_{39}\right)\left(\mathrm{H}_{2} \mathrm{O}\right)_{n}{ }^{6}\right]$ with an excitation wavelength of $292 \mathrm{~nm}$ was omitted from Figure 6 (see part B) because it resembles that obtained at $395 \mathrm{~nm}$, thus strongly suggesting a single $\mathrm{Eu}^{3+}$ environment. At this point it should be noted that the PL results for this material do not preclude the existence of a minor second phase comprising a quasi-crystalline $\mathrm{K}^{+} / \mathrm{Zn}^{2+} / \mathrm{Al}^{3+}$ salt of the POM $\left[\mathrm{Eu}\left(\mathrm{BW}_{11} \mathrm{O}_{39}\right)\left(\mathrm{H}_{2} \mathrm{O}\right)_{n}\right]^{6-}$, the existence of which is indicated by the powder XRD and ${ }^{11} \mathrm{~B}$ MAS NMR results.

In order to further investigate the number of distinct $\mathrm{Eu}^{3+}$ local coordination sites in each material the PL and the lifetimes of the ${ }^{5} \mathrm{D}_{0}$ excited state were acquired at lowtemperature for the same excitation wavelengths used to record the room-temperature emission. The number of $\mathrm{Eu}^{3+}$ local coordination sites can be inferred through the analysis of the energy and fwhm of the ${ }^{5} \mathrm{D}_{0} \rightarrow{ }^{7} \mathrm{~F}_{0}$ transition, estimated by deconvoluting the spectrum assuming a Gaussian function. The analysis of the energy and fwhm of the ${ }^{5} \mathrm{D}_{0} \rightarrow{ }^{7} \mathrm{~F}_{0}$ transition is quite important, since this transition occurs between nondegenerated levels and its energy is usually correlated with the sum of the nephelauxetic effects arising from the $\mathrm{Eu}^{3+}$ first neighbours. ${ }^{[47]}$ The existence of more than one line or the variation of its energy and fwhm upon variation of the excitation wavelength suggest the presence of more than one $\mathrm{Eu}^{3+}$ local coordination site. Figure 7 shows the low temperature PL spectra for the three LDH-POM samples.

For $\mathrm{ZnAl}\left[\mathrm{Eu}\left(\mathrm{BW}_{11} \mathrm{O}_{39}\right)\left(\mathrm{H}_{2} \mathrm{O}\right)_{n}{ }^{6}\right]$ the data collected at low temperature support the conclusion drawn from the room temperature $\mathrm{PL}$ spectra, i.e. that the europium ions occupy the same average local coordination site, since the spectra obtained under different excitation wavelengths are essentially the same. Moreover, the energy and fwhm of the ${ }^{5} \mathrm{D}_{0} \rightarrow{ }^{7} \mathrm{~F}_{0}$ transition is independent of the selected excitation wavelength (Table 5). The nature of this local environment must involve a low site symmetry group without 


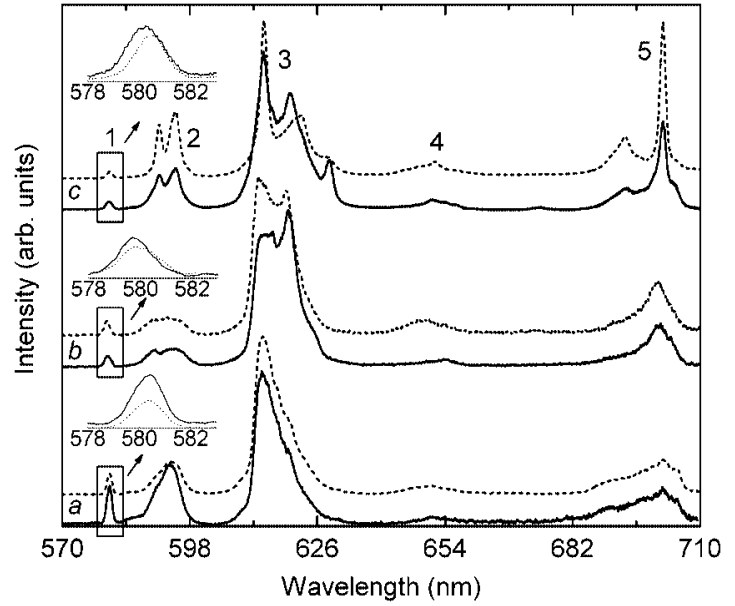

Figure 7. Emission spectra $(10 \mathrm{~K})$ for the $\mathrm{LDH}$ intercalates $\mathrm{ZnAl}$ $\left[\mathrm{Eu}\left(\mathrm{BW}_{11} \mathrm{O}_{39}\right)\left(\mathrm{H}_{2} \mathrm{O}\right)_{n}{ }^{6-}\right]$ (a), $\mathrm{ZnAl}\left[\mathrm{EuW}_{10} \mathrm{O}_{36}{ }^{9-}\right]$ (b) and $\mathrm{ZnAl}-$ $\left[\mathrm{Eu}\left(\mathrm{PW}_{11} \mathrm{O}_{39}\right)_{2}{ }^{11-}\right]$ (c) excited at 292 (solid line) and $395 \mathrm{~nm}$ (dotted line). (1), (2), (3), (4) and (5) denote the ${ }^{5} \mathrm{D}_{0} \rightarrow{ }^{7} \mathrm{~F}_{0-2}$ transitions, respectively.

inversion centre according to the number of components for the ${ }^{5} \mathrm{D}_{0} \rightarrow{ }^{7} \mathrm{~F}_{0-2}$ transitions (1, 3 and 4 , respectively) and the higher intensity of the ${ }^{5} \mathrm{D}_{0} \rightarrow{ }^{7} \mathrm{~F}_{2}$ lines, respectively.

For the other two LDH-POM samples, changes are observed in the number, energy, fwhm and relative intensity of the ${ }^{5} \mathrm{D}_{0} \rightarrow{ }^{7} \mathrm{~F}_{0-2}$ components as the excitation wavelength increases from 292 to $395 \mathrm{~nm}$. Increasing the excitation wavelength for $\mathrm{ZnAl}\left[\mathrm{EuW}_{10} \mathrm{O}_{36}{ }^{9-}\right]$ induces a reduction of the fwhm and a blue-shift of the ${ }^{5} \mathrm{D}_{0} \rightarrow{ }^{7} \mathrm{~F}_{0}$ transition, suggesting the presence of more than one type of first coordination sphere for the europium ions. Moreover, changes are also observed in the energy and relative intensity of components for the remaining transitions. The presence of at least two distinct local coordination sites for the $\mathrm{Eu}^{3+}$ cations is also apparent for $\mathrm{ZnAl}\left[\mathrm{Eu}\left(\mathrm{PW}_{11} \mathrm{O}_{39}\right)_{2}{ }^{11-}\right]$. Upon varying the excitation wavelength from 262 to $395 \mathrm{~nm}$ the fwhm and the energy of the ${ }^{5} \mathrm{D}_{0} \rightarrow{ }^{7} \mathrm{~F}_{0}$ transition decrease. An increase in the relative intensity of the ${ }^{5} \mathrm{D}_{0} \rightarrow{ }^{7} \mathrm{~F}_{1}$ transition and a decrease in the intensity of the ${ }^{5} \mathrm{D}_{0} \rightarrow{ }^{7} \mathrm{~F}_{2}$ transition are also detected. These results support the interpretation of the ${ }^{31} \mathrm{P}$ MAS NMR spectrum, that is, the co-intercalation of $\left[\mathrm{Eu}\left(\mathrm{PW}_{11} \mathrm{O}_{39}\right)_{2}\right]^{11-}$ and $\left[\mathrm{Eu}\left(\mathrm{PW}_{11} \mathrm{O}_{39}\right)\left(\mathrm{H}_{2} \mathrm{O}\right)_{n}\right]^{4-}$ anions.

The ${ }^{5} \mathrm{D}_{0}$ lifetime was measured at low temperature using two different excitation wavelengths (292 and $395 \mathrm{~nm}$ ) and a monitoring wavelength around the more intense line of the ${ }^{5} \mathrm{D}_{0} \rightarrow{ }^{7} \mathrm{~F}_{2}$ transition (not shown). Regardless of the selected excitation wavelength, the experimental data for
$\mathrm{ZnAl}\left[\mathrm{Eu}\left(\mathrm{BW}_{11} \mathrm{O}_{39}\right)\left(\mathrm{H}_{2} \mathrm{O}\right)_{n}{ }^{6}\right]$ are well reproduced by a single exponential function, revealing a lifetime value of $0.255 \pm 0.002 \mathrm{~ms}$ (Table 4 ), which further confirms the existence of a single $\mathrm{Eu}^{3+}$ coordination site in this material. For $\mathrm{ZnAl}\left[\mathrm{EuW}_{10} \mathrm{O}_{36}{ }^{9-}\right]$, the decay curve is also well reproduced by a single exponential, but different lifetime values of $0.347 \pm 0.003$ and $0.289 \pm 0.001$ were obtained for excitation wavelengths around 292 and $395 \mathrm{~nm}$, respectively (Table 5). The decay curves for $\mathrm{ZnAl}\left[\mathrm{Eu}\left(\mathrm{PW}_{11} \mathrm{O}_{39}\right)_{2}{ }^{11-}\right]$ revealed a two-exponential behaviour for the two selected excitation wavelengths, indicating lifetime values of $0.324 \pm 0.002$ and $2.950 \pm 0.118 \mathrm{~ms}$.

We can estimate the efficiency, $q$, of the ${ }^{5} \mathrm{D}_{0} \mathrm{Eu}^{3+}$ excited state. Assuming that only nonradiative and radiative processes are essentially involved in the depopulation of the ${ }^{5} \mathrm{D}_{0}$ state, $q$ can be defined as shown in Equation (1)

$q=\frac{k_{r}}{k_{r}+k_{m r}}$

where $k_{\mathrm{r}}$ and $k_{n \mathrm{r}}$ are the radiative and the nonradiative transition probabilities, respectively.

The emission intensity, $I$, taken as the integrated intensity $S$ of the emission curves, for the ${ }^{5} \mathrm{D}_{0} \rightarrow{ }^{7} \mathrm{~F}_{0-4}$ transitions, is expressed by Equation (2)

$I_{i \rightarrow j}=\hbar w_{i \rightarrow j} A_{i \rightarrow j} N_{i} \equiv S_{i \rightarrow j}$

where $i$ and $j$ represent the initial $\left({ }^{5} \mathrm{D}_{0}\right)$ and final $\left({ }^{7} \mathrm{~F}_{0-4}\right)$ levels, respectively, $\hbar w_{i \rightarrow j}$ is the transition energy, $A_{i \rightarrow j}$ corresponds to Einstein's coefficient of spontaneous emission and $N_{i}$ is the population of the ${ }^{5} \mathrm{D}_{0}$ emitting level. ${ }^{[47 b]}$ The radiative contribution may be calculated from the relative intensities of the ${ }^{5} \mathrm{D}_{0} \rightarrow{ }^{7} \mathrm{~F}_{0-4}$. The branching ratio for the ${ }^{5} \mathrm{D}_{0} \rightarrow{ }^{7} \mathrm{~F}_{5,6}$ transitions must be neglected as they are not observed experimentally. Their influence on the depopulation of the ${ }^{5} \mathrm{D}_{0}$ excited state can therefore be ignored. Since the ${ }^{5} \mathrm{D}_{0} \rightarrow{ }^{7} \mathrm{~F}_{1}$ transition can be considered as a reference, due to its dipolar magnetic nature, $k_{\mathrm{r}}$ can be calculated as shown in Equation (3)

$k_{r}=A_{0 \rightarrow 1} \frac{\hbar \omega_{0 \rightarrow 1}}{S_{0 \rightarrow 1}} \sum_{J=0}^{4} \frac{S_{0-J}}{\hbar \omega_{0-J}}$

where $A_{0-1}$ is Einstein's coefficient of spontaneous emission between the ${ }^{5} \mathrm{D}_{0}$ and the ${ }^{7} \mathrm{~F}_{1}$ Stark levels. The ${ }^{5} \mathrm{D}_{0} \rightarrow{ }^{7} \mathrm{~F}_{1}$ transition does not depend on the local ligand field seen by $\mathrm{Eu}^{3+}$ ions and, thus, may be used as a reference for the

Table 5. Energy, $E,\left[\mathrm{~cm}^{-1}\right]$ and fwhm $\left[\mathrm{cm}^{-1}\right]$ of the ${ }^{5} \mathrm{D}_{0} \rightarrow{ }^{7} \mathrm{~F}_{0}$ transition at different excitation wavelengths (292 and $\left.395 \mathrm{~nm}\right)$ for the anion-pillared layered double hydroxides.

\begin{tabular}{|c|c|c|c|c|}
\hline Sample & $\begin{array}{l}292 \mathrm{~nm} \\
E\end{array}$ & fwhm & $\begin{array}{l}395 \mathrm{~nm} \\
E\end{array}$ & fwhm \\
\hline $\mathrm{ZnAl}\left[\mathrm{Eu}\left(\mathrm{BW}_{11} \mathrm{O}_{39}\right)\left(\mathrm{H}_{2} \mathrm{O}\right)_{n}{ }^{6-}\right]$ & $17231.4 \pm 0.5$ & $33 \pm 1$ & $17231.1 \pm 0.1$ & $34 \pm 1$ \\
\hline $\mathrm{ZnAl}\left[\mathrm{EuW}_{10} \mathrm{O}_{36^{9}}{ }^{9}\right]$ & $17242.2 \pm 0.4$ & $42 \pm 1$ & $17247.5 \pm 0.4$ & $36 \pm 1$ \\
\hline $\mathrm{ZnAl}\left[\mathrm{Eu}\left(\mathrm{PW}_{11} \mathrm{O}_{39}\right)_{2}{ }^{11-}\right]$ & 17234.4 & $42 \pm 1$ & $17228.4 \pm 0.2$ & $36 \pm 1$ \\
\hline
\end{tabular}


Table 6. Quantum efficiency, $q[\%]$, experimental, $k_{\exp }\left[\mathrm{ms}^{-1}\right]$, radiative, $k_{\mathrm{r}}\left[\mathrm{ms}^{-1}\right]$, and the nonradiative, $k_{n \mathrm{r}}\left[\mathrm{ms}^{-1}\right]$, transition probabilities of the ${ }^{5} \mathrm{D}_{0}$ level for the polyoxotungstoeuropate salts and the $\mathrm{LDH}$ intercalate $\mathrm{ZnAl}\left[\mathrm{Eu}\left(\mathrm{BW}_{11} \mathrm{O}_{39}\right)\left(\mathrm{H}_{2} \mathrm{O}\right)_{n}{ }^{6-}\right]$.

\begin{tabular}{lllll}
\hline & {$\left[\mathrm{Eu}\left(\mathrm{PW}_{11} \mathrm{O}_{39}\right)_{2}\right]^{11-}$} & {$\left[\mathrm{EuW}_{10} \mathrm{O}_{36}\right]^{9-}$} & {$\left[\mathrm{Eu}\left(\mathrm{BW}_{11} \mathrm{O}_{39}\right)\left(\mathrm{H}_{2} \mathrm{O}\right)_{3}\right]^{6-}$} & $\mathrm{ZnAl}\left[\mathrm{Eu}\left(\mathrm{BW}_{11} \mathrm{O}_{39}\right)\left(\mathrm{H}_{2} \mathrm{O}\right)_{n}{ }^{6-}\right]$ \\
\hline$k_{\exp }$ & 0.480 & 0.353 & 3.309 & 3.922 \\
$k_{\mathrm{r}}$ & 0.153 & 0.139 & 0.260 & 0.298 \\
$k_{n \mathrm{r}}$ & 0.326 & 0.215 & 3.049 & 3.623 \\
$q$ & 32.0 & 39.2 & 7.9 & 7.6 \\
\hline
\end{tabular}

whole spectrum; in vacuo $A_{0-1}=14.65 \mathrm{~s}^{-1} \cdot{ }^{[48]}$ An effective refractive index of 1.5 was used. It was not possible to evaluate the $q$ value for the $\mathrm{LDH}$ intercalates $\mathrm{ZnAl}$ $\left[\mathrm{EuW}_{10} \mathrm{O}_{36}{ }^{9-}\right]$ and $\mathrm{ZnAl}\left[\mathrm{Eu}\left(\mathrm{PW}_{11} \mathrm{O}_{39}\right)_{2}{ }^{11-}\right]$, due to the presence of more than one local coordination site for the metal ions. Since it was not possible to selectively excite the emission ascribed to each $\mathrm{Eu}^{3+}$ ion, the emission intensity, $I$, cannot be determined independently, thus preventing any ${ }^{5} \mathrm{D}_{0}$ quantum efficiency calculations.

The quantum efficiency value for the compound $\mathrm{K}_{5} \mathrm{H}\left[\mathrm{Eu}\left(\mathrm{BW}_{11} \mathrm{O}_{39}\right)\left(\mathrm{H}_{2} \mathrm{O}\right)_{3}\right]$ is lower than those for the other two polyoxotungstoeuropate salts, essentially due to a higher nonradiative transition probability, that may be due to a higher number of coordinated water molecules (Table 6). Although the radiative transition probability for the $\mathrm{LDH}$ intercalate $\mathrm{ZnAl}\left[\mathrm{Eu}\left(\mathrm{BW}_{11} \mathrm{O}_{39}\right)\left(\mathrm{H}_{2} \mathrm{O}\right)_{3}{ }^{6-}\right]$ is higher, there is also an increase in the nonradiative transition probability, contributing to a slight decrease of the overall ${ }^{5} \mathrm{D}_{0}$ quantum efficiency.

\section{Conclusions}

A new family of luminescent materials has been prepared by treatment of a $\mathrm{Zn}-\mathrm{Al}$ layered double hydroxide in nitrate form with different polyoxotungstoeuropate anions. The photoluminescence studies, in conjunction with elemental analysis, powder XRD, IR and Raman spectroscopy, and solid state MAS NMR, allow us to construct a detailed picture of the possible nature of the intercalated anions. After ion exchange with an aqueous solution of $\mathrm{K}_{5} \mathrm{H}[\mathrm{Eu}-$ $\left.\left(\mathrm{BW}_{11} \mathrm{O}_{39}\right)\left(\mathrm{H}_{2} \mathrm{O}\right)_{3}\right]$, powder XRD, elemental analysis for $\mathrm{W}$ and $\mathrm{Eu}$, vibrational and ${ }^{11} \mathrm{~B}$ MAS NMR spectroscopy strongly indicate that the guest species in the resultant material, $\mathrm{ZnAl}\left[\mathrm{Eu}\left(\mathrm{BW}_{11} \mathrm{O}_{39}\right)\left(\mathrm{H}_{2} \mathrm{O}\right)_{n}{ }^{6-}\right]$, are monomeric $1: 1$ $\left[\mathrm{Eu}\left(\mathrm{BW}_{11} \mathrm{O}_{39}\right)\left(\mathrm{H}_{2} \mathrm{O}\right)_{n}\right]^{6-}$ anions, which give rise to a gallery height of about $10 \AA$. The photoluminescence data acquired at room temperature and also at low temperature confirm the existence of a single $\mathrm{Eu}^{3+}$ coordination site in this material. Overall, the room-temperature excitation and emission spectra for the pillared LDH are not very different from those for the potassium salt, $\mathrm{K}_{5} \mathrm{H}\left[\mathrm{Eu}\left(\mathrm{BW}_{11} \mathrm{O}_{39}\right)\left(\mathrm{H}_{2} \mathrm{O}\right)_{3}\right]$. Slight differences were, however, observed in the lifetimes and transition probabilities of the ${ }^{5} \mathrm{D}_{0}$ level. Ion exchange of the starting $\mathrm{LDH}$ compound with a solution of $\mathrm{K}_{11^{-}}$$\left[\mathrm{Eu}\left(\mathrm{PW}_{11} \mathrm{O}_{39}\right)_{2}\right]$ also gave a pillared derivative with a gallery height close to $10 \AA$. The photoluminescence data for this material show the presence of at least two distinct local coordination sites for the $\mathrm{Eu}^{3+}$ cations, which supports the interpretation of the ${ }^{31} \mathrm{P}$ MAS NMR spectrum, that is, the assignment of two of the peaks to co-intercalated 2:1 $\left[\mathrm{Eu}\left(\mathrm{PW}_{11} \mathrm{O}_{39}\right)_{2}\right]^{11-}$ and 1:1 $\left[\mathrm{Eu}\left(\mathrm{PW}_{11} \mathrm{O}_{39}\right)\left(\mathrm{H}_{2} \mathrm{O}\right)_{n}\right]^{4-}$ anions. The ${ }^{31} \mathrm{P}$ MAS NMR spectrum also indicates the presence of uncoordinated $\left[\mathrm{PW}_{11} \mathrm{O}_{39}\right]^{7-}$ anions. All three of these species could conceivably give rise to pillared LDHs with gallery heights around $10 \AA$. Deconvolution of the ${ }^{31} \mathrm{P}$ MAS NMR spectrum showed that the 2:1 Eu-containing anion was the major species present. These results show that, regardless of the initial polyoxometalate species in solution, the nature of the final intercalated species can be different, presumably due to the strong host-guest interaction(s). This was especially evident for the anion $\left[\mathrm{EuW}_{10} \mathrm{O}_{36}\right]^{9-}$, which gave rise to a material containing intercalated anions with a quite different and, as yet, unknown structure. The observed basal spacing was only compatible with the presence of anions smaller than the decatungstometalate species, and the photoluminescence studies reveal the presence of more than one first coordination sphere for the lanthanide ions.

\section{Experimental Section}

Reagents and Materials: Commercial materials were of reagent grade or better and used without further purification. Literature methods were used to prepare sodium or potassium salts of the polyoxotungstoeuropate anions $\left[\mathrm{EuW}_{10} \mathrm{O}_{36}\right]^{9-},{ }^{[49]}[\mathrm{Eu}-$ $\left.\left(\mathrm{BW}_{11} \mathrm{O}_{39}\right)\left(\mathrm{H}_{2} \mathrm{O}\right)_{3}\right]^{6-},{ }^{[31]}$ and $\left[\mathrm{Eu}\left(\mathrm{PW}_{11} \mathrm{O}_{39}\right)_{2}\right]^{11-} \cdot{ }^{[50]}$ The $\mathrm{Zn}-\mathrm{Al}$ $\mathrm{LDH}$ starting material, $\mathrm{ZnAl}\left[\mathrm{NO}_{3}{ }^{-}\right]$, was prepared as described previously. ${ }^{[12]}$

Synthesis of Polyoxotungstoeuropate Anion-Pillared Layered Double Hydroxides: Anion-exchange reactions with a series of europiumcontaining polyoxotungstate anions were carried out on an aqueous slurry of $\mathrm{ZnAl}\left[\mathrm{NO}_{3}{ }^{-}\right]$, using the method described by Evans et al. (Table 1). ${ }^{[12]}$ A typical reaction scale was $12.5 \mathrm{~cm}^{3}$ and involved dropwise addition of an aqueous solution of the polyoxometalate (up to $100 \%$ in excess over that theoretically required for complete exchange) to the $\mathrm{ZnAl}\left[\mathrm{NO}_{3}{ }^{-}\right]$slurry. The mixtures were then stirred for 3 to $5 \mathrm{~h}$ in the temperature range of $60-70{ }^{\circ} \mathrm{C}$ (Table 1). Yields for approximately $0.25 \mathrm{~g}$ precursor clay: $\mathrm{ZnAl}\left[\mathrm{EuW}_{10} \mathrm{O}_{36}{ }^{9-}\right.$ ], $0.36 \mathrm{~g}$; $\mathrm{ZnAl}\left[\mathrm{Eu}\left(\mathrm{BW}_{11} \mathrm{O}_{39}\right)\left(\mathrm{H}_{2} \mathrm{O}\right)_{3}{ }^{6-}\right], \quad 0.42 \mathrm{~g} ; \quad \mathrm{ZnAl}\left[\mathrm{Eu}\left(\mathrm{PW}_{11} \mathrm{O}_{39}\right)_{2}{ }^{11-}\right]$, $0.30 \mathrm{~g}$.

Instrumentation: The $\mathrm{Zn}, \mathrm{Al}, \mathrm{Eu}, \mathrm{W}$ and $\mathrm{P}$ contents were measured by Inductively Coupled Plasma-Atomic Emission Spectrometry (ICP-AES, Analytical Laboratories, University of Aveiro). FT-IR spectra were collected from $\mathrm{KBr}$ pellets (Aldrich, 99\%+, FT-IR grade) with a Mattson 7000 FT-IR spectrometer. FT-Raman spectra were recorded with a Bruker RFS100/S FT-Raman spectrometer (Nd:YAG laser, $1064 \mathrm{~nm}$ excitation). ${ }^{11} \mathrm{~B},{ }^{27} \mathrm{Al}$ and ${ }^{31} \mathrm{P}$ MAS NMR spectra were recorded with a Bruker Avance 400 spectrometer at, respectively, 128.37, 104.26 and $161.97 \mathrm{MHz}$, using spinning rates of $14 \mathrm{kHz}$. The ${ }^{31} \mathrm{P}$ MAS NMR spectra were recorded with 
$45^{\circ}$ pulses and $50 \mathrm{~s}$ recycle delays. The ${ }^{27} \mathrm{Al}$ MAS NMR spectra were recorded with $9^{\circ}$ pulses and $1 \mathrm{~s}$ recycle delays. The ${ }^{11} \mathrm{~B}$ MAS NMR spectra were recorded with $15^{\circ}$ pulses and $5 \mathrm{~s}$ recycle delays. Chemical shifts are quoted in ppm from $\mathrm{BF}_{3} \cdot \mathrm{O}\left(\mathrm{C}_{2} \mathrm{H}_{5}\right)_{2}\left({ }^{11} \mathrm{~B}\right)$, $\mathrm{Al}\left(\mathrm{H}_{2} \mathrm{O}\right)_{6}{ }^{3+}\left({ }^{27} \mathrm{Al}\right)$ and $85 \% \mathrm{H}_{3} \mathrm{PO}_{4}\left({ }^{31} \mathrm{P}\right)$. Powder XRD data were collected at room temperature with a Philips $\mathrm{X}^{\prime}$ pert diffractometer operating at $40 \mathrm{kV}$ and $50 \mathrm{~mA}$ using $\mathrm{Cu}-K_{\alpha}$ radiation. The diffractometer was equipped with a curved graphite monochromator, in a Bragg-Brentano para-focusing optics configuration. The $\mathrm{ZnAl}\left[\mathrm{NO}_{3}^{-}\right]$sample was step-scanned in $0.05^{\circ} 2 \theta$ steps with a counting time of $1 \mathrm{~s}$ per step. For the other samples, a step size of $0.02^{\circ} 2 \theta$ was used with a counting time of $16 \mathrm{~s}$ per step. The roomtemperature emission and excitation spectra of the LDHs were recorded using a Jobin Yvon-Spex spectrometer (HR, 460) coupled to a R928 Hamamatsu photomultiplier. A Xe arc lamp (150 mW) coupled to a Jobin Yvon monochromator (TRIAX 180) was used as the excitation source. All of the spectra were corrected for the response of the detector. The room-temperature photoluminescence of the POMs and the spectra and lifetimes recorded at lowtemperature $(10 \mathrm{~K})$ were detected with a modular double grating excitation spectrofluorimeter with a TRIAX 320 emission monochromator (Fluorolog-3, Jobin Yvon-Spex) coupled to a R928 Hamamatsu photomultiplier, in the front face acquisition mode. All of the photoluminescence spectra were corrected for optics and detection spectral response.

\section{Acknowledgments}

We are grateful to the Fundação para a Ciência e a Tecnologia (FCT, Portugal) for their general financial support under the POCTI program (supported by FEDER).

[1] V. Rives (Ed.), Layered Double Hydroxides: Present and Future, Nova Science Publishers, Inc., New York, 2001.

[2] A. I. Khan, D. O'Hare, J. Mater. Chem. 2002, 12, 3191.

[3] S. P. Newman, W. Jones, New J. Chem. 1998, 22, 105.

[4] V. Rives, M. A. Ulibarri, Coord. Chem. Rev. 1999, 181, 61.

[5] G. M. Woltermann, US Pat., 4454 244, 1984.

[6] T. Kwon, G. A. Tsigdinos, T. J. Pinnavaia, J. Am. Chem. Soc. 1988, $110,3653$.

[7] M. A. Drezdon, Inorg. Chem. 1988, 27, 4628.

[8] T. Kwon, T. J. Pinnavaia, Chem. Mater. 1989, 1, 381.

[9] E. D. Dimotakis, T. J. Pinnavaia, Inorg. Chem. 1990, 29, 2393.

[10] J. Wang, Y. Tian, R.-C. Wang, A. Clearfield, Chem. Mater. 1992, 4, 1276.

[11] E. Narita, P. D. Kaviratna, T. J. Pinnavaia, J. Chem. Soc. Chem. Commun. 1993, 60.

[12] J. Evans, M. Pillinger, J. Zhang, J. Chem. Soc. Dalton Trans. 1996, 2963.

[13] S. K. Yun, T. J. Pinnavaia, Inorg. Chem. 1996, 35, 6853.

[14] E. A. Gardner, S. K. Yun, T. Kwon, T. J. Pinnavaia, Appl. Clay Sci. 1998, 13, 479.

[15] M. R. Weir, R. A. Kydd, Inorg. Chem. 1998, 37, 5619.

[16] C. Barriga, W. Jones, P. Malet, V. Rives, M. A. Ulibarri, Inorg. Chem. 1998, 37, 1812.

[17] H. Nijs, M. de Bock, E. F. Vansant, J. Porous Mater. 1999, 6, 101.

[18] Y. Guo, D. Li, C. Hu, Y. Wang, E. Wang, Int. J. Inorg. Mater. 2001, 3, 347.

[19] T. Yamase, M. Sugeta, J. Chem. Soc. Dalton Trans. 1993, 759.

[20] T. Yamase, T. Kobayashi, M. Sugeta, H. Naruke, J. Phys. Chem. A 1997, 101, 5046.

[21] J. Bartis, M. Dankova, J. J. Lessmann, Q. Luo, W. D. Horrocks, L. C. Francesconi, Inorg. Chem. 1999, 38, 1042.
[22] Q. Luo, R. C. Howell, J. Bartis, M. Dankova, W. D. Horrocks, A. L. Rheingold, L. C. Francesconi, Inorg. Chem. 2002, 41, 6112.

[23] C. Zhang, R. C. Howell, K. B. Scotland, F. G. Perez, L. Todaro, L. C. Francesconi, Inorg. Chem. 2004, 43, 7691.

[24] W. Xu, Q. Luo, H. Wang, L. C. Francesconi, R. E. Stark, D. L. Akins, J. Phys. Chem. B 2003, 107, 497.

[25] L. Xu, H. Zhang, E. Wang, D. G. Kurth, Z. Li, J. Mater. Chem. 2002, 12, 654 .

[26] Y. Wang, X. Wang, C. Hu, C. Shi, J. Mater. Chem. 2002, 12, 703.

[27] J. Wang, H. Wang, F. Liu, L. Fu, H. Zhang, J. Lumin. 2003, 101, 63.

[28] H. Y. Zhang, L. Xu, E. B. Wang, M. Jiang, A. G. Wu, Z. Li, Mater. Lett. 2003, 57, 1417.

[29] W. Bu, L. Wu, X. Zhang, A.-C. Tang, J. Phys. Chem. B 2003, 107, 13425.

[30] H. Ma, J. Peng, Z. Han, Y. Feng, E. Wang, Thin Solid Films 2004, 446, 161.

[31] F. L. Sousa, A. C. A. S. Ferreira, R. A. Sá Ferreira, A. M. V. Cavaleiro, L. D. Carlos, H. I. S. Nogueira, J. Rocha, T. Trindade, J. Nanosci. Nanotechnol. 2004, 4, 214.

[32] C. Zhang, R. C. Howell, W. Xu, Q.-H. Luo, D. L. Akins, L. C. Francesconi, Technical Proceedings of the 2003 Nanotechnology Conference and Trade Show, vol. 3, pp. 235-238.

[33] J. J. Bravo-Suárez, E. A. Páez-Mozo, S. T. Oyama, Chem. Mater. 2004, 16, 1214.

[34] M. Bellotto, B. Rebours, O. Clause, J. Lynch, D. Bazin, E. Elkaïm, J. Phys. Chem. 1996, 100, 8527.

[35] T. Yamase, T. Ozeki, K. Ueda, Acta Crystallogr. Sect. C: Cryst. Struct. Commun. 1993, 49, 1572.

[36] C. Vaysse, L. Guerlou-Demourgues, A. Demourgues, F. Lazartigues, D. Fertier, C. Delmas, J. Mater. Chem. 2002, 12, 1035.

[37] M. del Arco, D. Carriazo, S. Gutiérrez, C. Martín, V. Rives, Inorg. Chem. 2004, 43, 375, and references therein.

[38] C. Rocchiccioli-Deltcheff, M. Fournier, R. Franck, R. Thouvenot, Inorg. Chem. 1983, 22, 207.

[39] A. M. V. Cavaleiro, J. D. Pedrosa de Jesus, H. I. S. Nogueira, Metal Clusters in Chemistry (Eds.: P. Braunstein, L. A. Oro, P. Raithby), Wiley-VCH, Weinheim, 1999, vol. 1, pp. 444 458.

[40] A. R. Couto, C. N. Trovão, J. Rocha, A. M. V. Cavaleiro, J. D. Pedrosa de Jesus, J. Chem. Soc. Dalton Trans. 1994, 2585.

[41] F. L. Sousa, F. A. A. Paz, C. M. C. E. Granadeiro, A. M. V. Cavaleiro, J. Rocha, J. Klinowski, H. I. S. Nogueira, Inorg. Chem. Commun. 2005, 8, 924.

[42] M. Sadakane, M. H. Dickman, M. T. Pope, Angew. Chem. Int. Ed. 2000, 39, 2914.

[43] W. P. Griffith, N. Morley-Smith, H. I. S. Nogueira, A. G. F. Shoair, M. Suriaatmaja, A. J. P. White, D. J. Williams, J. Organomet. Chem. 2000, 607, 146.

[44] S. Gago, M. Pillinger, A. A. Valente, T. M. Santos, J. Rocha, I. S. Gonçalves, Inorg. Chem. 2004, 43, 5422, and references therein.

[45] M. Sugeta, T. Yamase, Bull. Chem. Soc. Jpn. 1993, 66, 444.

[46] R. Ballardinni, Q. G. Mulazzani, M. Venturini, F. Bolletta, B. Balzani, Inorg. Chem. 1984, 23, 300.

[47] a) L. D. Carlos, R. A. Sá Ferreira, V. de Zea Bermudez, C. Molina, L. A. Bueno, S. J. L. Ribeiro, Phys. Rev. B 1999, 60, 10042; b) L. D. Carlos, Y. Messaddeq, H. F. Brito, R. A. Sá Ferreira, V. de Zea Bermudez, S. J. L. Ribeiro, Adv. Mater. 2000, 12, 594; c) R. A. Sá Ferreira, L. D. Carlos, R. R. Goncalves, S. J. L. Ribeiro, V. de Zea Bermudez, Chem. Mater. 2001, 13, 2991.

[48] M. H. V. Werts, R. T. F. Jukes, J. W. Verhoeven, Phys. Chem. Chem. Phys. 2002, 4, 1542.

[49] R. D. Peacock, T. J. R. Weakley, J. Chem. Soc. (A) 1971, 1836.

[50] N. Haraguchi, Y. Okaue, T. Isobe, Y. Matsuda, Inorg. Chem. 1994, 33, 1015 .

Received: June 9, 2005

Published Online: December 20, 2005 